\title{
PELIBATAN ANAK DI DALAM KAMPANYE POLITIK PADA PEMILIHAN BUPATI DAN WAKIL BUPATI PERIODE 2019-2024 DI KABUPATEN CIAMIS
}

\author{
Oleh : \\ Dr. Ida Farida S.H., M.H. ${ }^{*}$ \\ Idafarida.galuh@gmail.com \\ Vera Fillinda Agustiana Dewi, S.H., M.H. ${ }^{\text {(x) }}$ \\ verafadewi@gmail.com
}

\begin{abstract}
The simultaneous election campaign period of 2018 carried out in 171 regions in Indonesia has been carried out. This five-yearly democratic party certainly involves public participation, including those who are vulnerable to abuse for political activities, namely children. Although Article 15 point (a) of the Law of the Republic of Indonesia Number 35 of 2014 concerning Amendments to the Law of the Republic of Indonesia Number 23 of 2002 concerning Child Protection confirms the prohibition on child abuse for political activities, but in its implementation there is still involvement of children in activities the campaign.

As a means of implementing popular sovereignty, general elections after the amendment to the 1945 Constitution of the Republic of Indonesia experienced very rapid development. This was marked by the high level of need for electoral rules and the many types of elections that had to be carried out in one period of government. However, these developments also have an impact on the emergence of complexity. At the very least, the development of the Indonesian elections was characterized by the vulnerability of disharmony and rule uncertainty, tensions between institutions involved in the administration, and uncertainty in the process of law enforcement and resolution of electoral disputes.

The involvement of children in political campaigns is a violation of children's rights in accordance with Article 15 point (a) of the Law of the Republic of Indonesia Number 23 of 2002 concerning Child Protection which states that every child has the right to protection from abuse in political activities. This means that the law has at the same time regulated the prohibition of involving children in any political campaign. To avoid involving children in campaigns and practical politics, a campaign should be carried out all the way before the time the campaign arrives, with family targets and targets not to allow or invite children in the election campaign. It is hoped that this democratic process can provide good examples of democracy, including in campaigns that are child-friendly, so that children can be maintained and grow well.
\end{abstract}

Keywords: Engagement, Children, Campaign.

Dosen Tetap Fakultas Hukum Universitas Galuh

×* Alumni Fakultas Hukum Universitas Galuh dan Pengurus KPAI Kabupaten Ciamis. 


\begin{abstract}
ABSTRAK
Masa kampanye Pilkada serentak tahun 2018 yang dilaksanakan di 171 daerah di Indonesia sudah dilaksanakan. Pesta demokrasi lima tahunan ini sudah pasti melibatkan partisipasi publik, tak terkecuali pihak yang rentan disalahgunakan untuk kegiatan politik yakni anak-anak. Walaupun Pasal 15 butir (a) UndangUndang Republik Indonesia Nomor 35 Tahun 2014 Tentang Perubahan UndangUndang Republik Indonesia Nomor 23 Tahun 2002 Tentang Perlindungan Anak menegaskan larangan mengenai penyalahgunaan anak untuk aktivitas politik, namun dalam pelaksanaannya masih saja tetap ada pelibatan anak dalam kegiatan kampanye tersebut.

Sebagai sarana pelaksanaan kedaulatan rakyat, pemilihan umum pasca perubahan Undang-Undang Dasar Republik Indonesia Tahun 1945 mengalami perkembangan yang amat pesat. Hal itu ditandai dengan tingginya tingkat kebutuhan akan aturan pemilu dan banyaknya jenis pemilu yang mesti dilaksanakan dalam satu periode pemerintahan. Hanya saja, perkembangan tersebut juga membawa dampak terhadap munculnya kompleksitas. Setidaknya, perkembangan dunia pemilu Indonesia diwarnai dengan kerawanan disharmoni dan ketidakpastian aturan, ketegangan antar institusi yang terlibat dalam penyelenggaraan, dan ketidakpastian proses penegakan hukum dan penyelesaian sengketa pemilu.

Pelibatan anak di dalam kampanye politik merupakan pelanggaran terhadap hak-hak anak sesuai dengan Pasal 15 butir (a) Undang-Undang Republik Indonesia Nomor 23 Tahun 2002 Tentang Perlindungan Anak yang meyatakan bahwa setiap anak berhak memperoleh perlindungan dari penyalahgunaan dalam kegiatan politik. Ini artinya undang-undang sudah sekaligus mengatur larangan pelibatan anak dalam kampanye politik apapun bentuknya. Untuk menghindari pelibatan anak dalam kampanye dan politik praktis, sudah seharusnya dilakukan suatu kampanye jauhjauh harus sebelum waktu kampanye tiba, dengan target dan sasaran keluarga untuk tidak mengijinkan atau mengajak anak-anak dalam kampanye pemilu. Diharapkan proses demokrasi ini bisa memberikan contoh-contoh baik berdemokrasi termasuk dalam kampanye yang ramah bagi anak, sehingga anak bisa terjaga tumbuh dan kembangnya dengan baik.
\end{abstract}

Kata kunci : Pelibatan, Anak, Kampanye.

\title{
I. PENDAHULUAN
}

Pemilihan kepala daerah (pilkada) sekarang ini dilakukan secara langsung. Hal ini telah berlangsung sejak tahun 2005 berdasarkan pada ketentuan Undang-Undang Republik Indonesia Nomor 32 Tahun 2004 Tentang Pemerintahan Daerah. Berlandaskan pada Pasal 18 ayat (4) Undang-Undang Dasar Negara Republik Indonesia Tahun 1945 yang menentukan bahwa Gubernur, Bupati, dan Walikota masing-masing sebagai kepala pemerintahan daerah Provinsi, Kabupaten, dan Kota dipilih secara demokratis.

Meskipun pemilihan secara langsung dipandang memiliki makna positif dari aspek legitimasi dan kompetensi, frasa "dipilih secara demokratis" 
sebagaimana dimaksud Pasal 18 ayat (4) Undang-Undang Dasar Negara Republik Indonesia Tahun 1945 tidak dapat diterjemahkan secara tunggal sebagai pemilihan secara langsung. Pemilihan secara tidak langsung atau perwakilan pun dapat diartikan sebagai pemilihan yang demokratis, sepanjang proses pemilihan dilakukan demokratis. (Leo Agustina, 2009: 79). Pemahaman ini didasarkan bahwa Negara Republik Indonesia berdasarkan Undang-Undang Dasar Negara Republik Indonesia Tahun 1945 mengakui dan menghormati satuan-satuan pemerintahan daerah yang bersifat khusus atau bersifat istimewa sebagaimana diatur dalam Pasal 18B Undang-Undang Dasar Negara Republik Indonesia Tahun 1945. Dengan demikian, pemahaman mendasar terhadap ketentuan pemilihan kepala daerah sebagaimana dimaksud Pasal 18 ayat (4) Undang-Undang Dasar Negara Republik Indonesia Tahun 1945 terutama terkait frasa "...dipilih secara demokratis" dapat dimaknai bahwa pemilihan kepala daerah dapat dilakukan dalam 2 (dua) cara, yaitu pemilihan secara langsung oleh rakyat atau pemilihan melalui perwakilan yang dilaksanakan oleh DPRD. (Nopyandri: 2018)

Masa kampanye Pilkada serentak tahun 2018 yang dilaksanakan di 171 daerah di Indonesia sudah dilaksanakan. Pemilihan kepala daerah secara langsung pada tanggal 27 Juni 2018 ini diharapkan bisa melahirkan pimpinan kepala daerah yang berkualitas dan sesuai dengan pilihan masyarakat di daerah. Pesta demokrasi lima tahunan ini sudah pasti melibatkan partisipasi publik, tak terkecuali pihak yang rentan disalahgunakan untuk kegiatan politik yakni anak-anak. Walaupun Pasal 15 butir (a) Undang-Undang Republik Indonesia Nomor 35 Tahun 2014 Tentang Perubahan Atas Undang-Undang Republik Indonesia Nomor 23 Tahun 2002 Tentang Perlindungan Anak menegaskan larangan mengenai penyalahgunaan anak untuk aktivitas politik, namun dalam pelaksanaannya masih saja tetap ada pelibatan anak dalam kegiatan kampanye tersebut.

Anak merupakan anugerah dari Tuhan Yang Maha Esa yang harus dijaga karena di dalam dirinya melekat harkat, martabat, dan hak-hak sebagai manusia yang harus dijunjung tinggi dan setiap anak yang terlahir harus mendapatkan hak-haknya tanpa anak tersebut meminta. Hak asasi anak merupakan bagian dari hak asasi manusia yang termaktub di dalam UndangUndang Dasar Negara Republik Indonesia Tahun 1945 dan Konvensi 
Perserikatan Bangsa-Bangsa (PBB) tentang Hak-Hak Anak. Di dalam kehidupan berbangsa dan bernegara, anak adalah masa depan bangsa dan generasi penerus cita-cita bangsa, sehingga setiap anak berhak atas kelangsungan hidup, tumbuh, berkembang, berpartisipasi, serta berhak atas perlindungan dari tindak kekerasan dan diskriminasi.

Anak sebagai generasi penerus merupakan aset yang penting dan menentukan dalam upaya menyiapkan dan mewujudkan masa depan bangsa dan negara. Seorang anak dilahirkan sebagai bentuk hubungan kasih sayang seorang suami dengan istri. Harapan begitu besar diserahkan pada seorang anak agar dalam kehidupannya kelak dapat membawa perubahan besar meningkatkan kesejahteraan manusia. Anak adalah harapan masa depan sebuah bangsa dan negara sehingga harus disiapkan sarana dan prasarana terutama pendidikan dan kesehatan. Tidak kalah pentingnya adalah perhatian dan kasih sayang dari keluarga maupun masyarakat agar anak kelak memiliki rasa optimis dalam menjalani kehidupannya. Mempersiapkan seorang anak untuk masa depannya yang baik adalah tugas bersama.

Kekurangtahuan masyarakat akan pentingnya perlindungan dan larangan pelibatan anak dalam aktivitas politik menjadi kendala. Dalam situasi riil politik dan perilaku politik saat ini, menyebabkan masih terjadinya penyalahgunaan dan pelanggaran hak anak dalam pelibatan aktivitas Pilkada serentak 2018

Apabila anak kurang mendapatkan perhatian dari lingkungan terdekatnya maka akan sangat mudah dipengaruhi untuk melakukan perbuatan yang menyimpang dari norma hukum yang berlaku di masyarakat. Akibatnya banyak yang menjurus kepada perbuatan kriminal yang membutuhkan penanganan hukum secara serius, khususnya perlindungan atas hak-hak anak.

Dalam Pasal 87 Undang-Undang Republik Indonesia Nomor 23 Tahun 2002 Tentang Perlindungan Anak mengancam setiap orang yang menyalahgunakan anak-anak dalam kegiatan politik dan militer lima tahun penjara atau denda maksimal Rp 100 juta. Pasal tersebut lengkapnya berbunyi: "Setiap orang secara melawan hukum merekrut atau memperalat anak untuk kepentingan militer sebagaimana dimaksud dalam pasal 63 atau penyalahgunaan dalam kegiatan politik dipidana dengan pidana penjara paling 
lama 5 (lima) tahun dan/atau denda paling banyak Rp100.000.000 (seratus juta rupiah)".

Meskipun ketentuan aturan hukum sudah ada, namun kita sering dihadapkan pada kenyataan bahwa ada anak-anak yang masih mengikuti kegiatan kampanye, baik dengan melihat secara langsung maupun informasi dari media sosial team sukses kampanye kandidat peserta pilkada padahal larangan dan ancaman sanksi pidananya itu sudah jelas.

Persoalan keterlibatan anak dalam kontestasi politik sangat jarang diungkap oleh berbagai pihak, hal ini disebabkan keterlibatan anak tersebut belum menjadi isu yang massal dan perlu mendapat perhatian dari semua pihak, bahkan yang sudah mengetahui adanya Undang-Undang Republik Indonesia Nomor 35 Tahun 2014 Tentang Perubahan Atas Undang-Undang Republik Indonesia Nomor 23 Tahun 2002 Tentang Perlindungan Anak pun seolah menutup mata ketika melihat langsung adanya partisipasi anak dalam kegiatan kampanye politik tersebut.

Tak bisa dipungkiri di Kabupaten Ciamis pun ada pelibatan anak di dalam penyelenggaraan kampanye pilkada serentak tahun 2018 ini, hal tersebut didapat dari pengamatan Penulis dalam kampanye pemilihan bupati dan wakil bupati Kabupaten Ciamis periode 2019-2024, sehingga Penulis tertarik untuk menulis artikel tentang "Pelibatan Anak di dalam Kampanye Politik pada Pemilihan Bupati dan Wakil Bupati Periode 2019-2024 di Kabupaten Ciamis."

\section{PEMBAHASAN}

Sebagai sarana pelaksanaan kedaulatan rakyat, pemilihan umum (pemilu) pasca perubahan Undang-Undang Dasar Negara Republik Indonesia Tahun 1945 mengalami perkembangan yang amat pesat. Hal itu ditandai dengan tingginya tingkat kebutuhan akan aturan pemilu dan banyaknya jenis pemilu yang mesti dilaksanakan dalam satu periode pemerintahan. Hanya saja, perkembangan tersebut juga membawa dampak terhadap munculnya kompleksitas. Setidaknya, perkembangan dunia pemilu Indonesia diwarnai dengan: kerawanan disharmoni dan ketidakpastian aturan, ketegangan antar institusi yang terlibat dalam penyelenggaraan, dan ketidakpastian proses penegakan hukum dan penyelesaian sengketa pemilu. Akibatnya, setiap 
tahapan pemilu atau pilkada akan dilaksanakan, nyaris selalu diwarnai keriuhan. (Saldi Isra, 2016: 1).

Masalah-masalah hukum pemilu di Indonesia dapat dikelompokkan ke dalam 6 kategori (Refly Harun, 2016: 288), yaitu :

1) Pelanggaran administrasi pemilu;

2) Tindak pidana pemilu;

3) Sengketa pemilu;

4) Sengketa tata usaha negara pemilu;

5) Pelanggaran kode etik penyelenggaraan pemilu; dan

6) Perselisihan hasil pemilu.

Instrumen hukum yang mengatur perlindungan hak-hak anak terdapat di dalam konvensi PBB tentang Hak-Hak Anak ( Convention of the Rights of the Child) Tahun 1989, telah diratifikasi oleh lebih dari 191 negara, termasuk Indonesia sebagai anggota PBB melalui Keputusan Presiden Nomor 36 Tahun 1990. Dengan demikian, Konvensi PBB tersebut telah menjadi hukum Indonesia dan mengikat seluruh warga negara Indonesia. (Rika Saraswati, $2015: 15)$

Terdapat 4 (empat) prinsip perlindungan anak berdasarkan Konvensi Hak Anak (KHA), yang menjadi dasar bagi setiap negara dalam menyelenggarakan perlindungan anak, diantaranya :

1) Prinsip Non Diskriminasi;

2) Prinsip Kepentingan Terbaik untuk Anak (Best Interest of The Child);

3) Prinsip Hak Hidup, Kelangsungan Hidup, dan Perkembangan (Right to Life, Survival,and Development);

4) Prinsip Penghargaan terhadap Pendapat Anak ( Respect for the views of the Child). (Hadi Supeno, 2010: 53)

Perlindungan hak anak apabila dikaitkan antara konsep negara hukum dengan negara demokrasi, dapat diketahui bahwa dalam prinsip negara hukum setiap anak berhak untuk memperoleh perlindungan atas penyalahgunaan dalam kegiatan politik, namun dalam konsepsi negara demokrasi setiap orang berhak ikut serta di dalam pemerintahan. Hal ini tidak menutup kemungkinan adanya penyalahgunaan anak dalam pelaksanaan demokrasi melalui pemilihan umum.

Komisi Perlindungan Anak Indonesia (KPAl) menyatakan setidaknya ada 15 modus pelanggaran kampanye yang dilakukan parpol dengan 
melibatkan anak pada penyelenggaraan kampanye pemilu tahun 2014 lalu, antara lain :

(1) memanipulasi data anak yang belum berusia 17 tahun dan belum menikah agar bisa didaftar menjadi pemilih;

(2) menggunakan tempat bermain anak, tempat penitipan anak, dan tempat pendidikan untuk kegiatan kampanye terbuka;

(3) memobilisasi massa anak oleh parpol atau caleg;

(4) menggunakan anak sebagai penganjur atau juru kampanye untuk memilih partai atau caleg tertentu;

(5) menampilkan anak sebagai bintang utama dari suatu iklan politik;

(6) menampilkan anak di atas panggung kampanye parpol dalam bentuk hiburan;

(7) menggunakan anak untuk memasang atribut-atribut parpol;

(8) menggunakan anak untuk melakukan pembayaran kepada pemilih dewasa dalam praktik politik uang oleh parpol atau caleg;

(9) mempersenjatai anak atau memberikan benda tertentu yang membahayakan dirinya atau orang lain;

(10) memaksa, membujuk, atau merayu anak untuk melakukan hal-hal yang dilarang selama kampanye, pemungutan suara, atau penghitungan suara;

(11) membawa anak ke arena kampanye yang membahayakan anak;

(12) melakukan tindak kekerasan atau yang dapat diartikan sebagai tindak kekerasan dalam kampanye, pemungutan suara, atau penghitungan suara (misal mengecat lambang parpol di bagian tubuh anak);

(13) melakukan pengucilan, penghinaan, intimidasi, atau tindakantindakan diskriminatif kepada anak yang orang tua atau keluarganya berbeda atau diduga berbeda pilihan politiknya;

(14) memprovokasi anak untuk memusuhi atau membenci caleg atau parpol tertentu; dan

(15) melibatkan anak dalam sengketa hasil perhitungan suara. (Liputan6.com, KPAI. 30 Agustus 2018).

Meskipun telah terbukti sudah melibatkan anak-anak dalam kampanye politik namun masih ada anggapan yang menyatakan bahwa hal ini merupakan salah satu cara untuk memberikan pendidikan politik pada anak sejak dini, akan tetapi sebaiknya harus disesuaikan dengan usia mereka yang masuk ketegori usia anak, yakni seseorang yang belum berusia 18 tahun dan mengedepankan prinsip-prinsip perlindungan anak.

Banyak pertimbangan mengapa anak dilarang dilibatkan dalam kegiatan politik, di antaranya adalah alasan ketidaksesuaian dengan perkembangan psikologis anak, alasan kenyamanan anak, hingga alasan terampasnya waktu anak untuk mengisi luang waktu yang berkualitas. Pasal 11 Undang-Undang Republik Indonesia Nomor 23 Tahun 2002 Tentang Perlindungan Anak 
menyebutkan : "setiap anak berhak beristirahat dan memanfaatkan waktu luang, bergaul dengan anak yang sebaya, bermain, berekreasi dan berkreasi sesuai dengan minat, bakat, dan tingkat kecerdasannya demi pengembangan diri".

Menurut KPAI masih ada pihak yang masih keberatan dengan larangan tersebut, karena menganggap bahwa pelibatan anak dalam kampanye sebenarnya tidak menjadi masalah. Asumsinya bahwa di dalam Konvensi Hak Anak (KHA) tidak ada satu pasal pun yang mengatur masalah tersebut. Akan tetapi yang ada justru sebaliknya, melibatkan anak dalam kampanye politik harus dianggap dapat membahayakan tumbuh kembang anak, karena tidak hanya dapat mengancam anak secara fisik seperti yang terjadi di arena kampanye terbuka dan arak-arakan kendaraan, akan tetapi secara psikis juga dapat mengganggu kejiwaan anak yang belum matang dan belum siap menerima persaingan yang keras dalam berpolitik, sehingga sudah seharusnya keberadaan Pasal 15 Undang-Undang Republik Indonesia Nomor 23 Tahun 2002 Tentang Perlindungan Anak menjadi dasar sebagai tindakan preventif untuk melindungi anak dari pelibatan kampanye politik.

Undang-Undang Republik Indonesia Nomor 23 Tahun 2002 Tentang Perlindungan Anak dan Undang-Undang Republik Indoneisa Nomor 35 Tahun 2014 Tentang Perubahan Atas Undang-Undang Republik Indonesia Nomor 23 Tahun 2002 Tentang Perlindungan Anak menegaskan bahwa pertanggungjawaban orang tua, keluarga, masyarakat, pemerintah, dan negara merupakan rangkaian kegiatan yang dilaksanakan secara terus menerus demi terlindunginya hak-hak anak. Rangkaian kegiatan tersebut harus berkelanjutan dan terarah guna menjamin pertumbuhan dan perkembangan anak, baik fisik, mental, spiritual, maupun sosial. Tindakan ini dimaksudkan untuk mewujudkan kehidupan terbaik bagi anak yang nantinya diharapkan sebagai penerus bangsa. Melalui Undang-Undang Republik Indonesia Nomor 35 Tahun 2014 Tentang Perubahan Atas Undang-Undang Republik Indonesia Nomor 23 Tahun 2002 Tentang Perlindungan Anak bertujuan untuk memberikan perlindungan terhadap anak-anak Indonesia dari segala bentuk diskriminasi dan kekerasan dipertegas. Undang-Undang Republik Indonesia Nomor 35 Tahun 2014 Tentang Perubahan Undang-Undang Republik Nomor 23 Tahun 2002 Tentang Perlindungan Anak telah menambahkan definisi kekerasan yang sebelumnya 
tidak ada di dalam Undang-Undang Republik Indoensia Nomor 23 Tahun 2002 Tentang Perlindungan Anak. Tujuan dibentuknya Undang-Undang Perlindungan anak adalah untuk melindungi anak dari segala bentuk kekerasan fisik, emosional, sosial dan seksual, penelantaran, tindakan membahayakan, eksploitasi : ekonomi,seksual, dan diskriminasi karena latar belakang ekonomi, politis, agama, sosial budaya, dan orang tuanya sehingga hak-hak anak agar dapat hidup, tumbuh, berkembang, dan berpartisipasi secara optimal, mendapatkan perlindungan dari kekerasan dan diskriminasi agar terwujud anak Indonesia yang berkualitas, berakhlak dan sejahtera. ( Rika Saraswati, 2015: 25)

Di dalam Pasal 15 Undang-Undang Republik Indonesia Nomor 35 Tahun 2014 Tentang Perubahan Atas Undang-Undang Nomor 23 Tahun 2002 Tentang Perlindungan Anak disebutkan bahwa anak juga berhak memperoleh perlindungan dari penyalahgunaan kegiatan politik, sengketa bersenjata, kerusuhan sosial, serta peristiwa yang mengandung unsur kekerasan dan perang. Ini artinya undang-undang sudah sekaligus mengatur larangan pelibatan anak dalam kampanye politik apapun bentuknya. Namun demikian meskipun ada aturannya, larangan menggunakan anak dalam kampanye atau pemilu tampaknya sulit diterapkan dan diawasi. Panitia Pengawas Pemilu (Panwaslu) pun seakan kesulitan melakukan pengawasan dan pemberian sangsi terhadap pelanggaran tersebut. Dalam setiap kegiatan massa parpol dan kampanye pengerahan massa, nyaris selalu diikuti anak-anak.

Beberapa bentuk pelibatan anak di dalam kampanye pada pelaksanaan pilkada pemilihan bupati dan wakil bupati Kabupaten Ciamis periode 2019-2024 yang telah dilaksanakan pada tanggal 27 Juni 2018, di antaranya foto kandidat bersama anak-anak dengan menunjukan jari tangan sebagai kode tanda dukungan kepada kandidat yang diupload ke media sosial seperti Facebook dan Instagram, keikutsertaan anak-anak saat pelaksanaan kampanye terbuka di lapangan Lokasana Ciamis, serta turut konvoi dalam mobil bak tanpa pelindung yang sudah tentu sangat membahayakan bagi diri anak-anak akan tetapi tidak ada kepedulian dari kaum dewasa bahwa hal tersebut merupakan sebuah pelanggaran terhadap Undang-Undang Perlindungan Anak (UUPA).

Untuk menghindari pelibatan anak dalam kampanye dan politik praktis, sudah seharusnya dilakukan suatu kampanye jauh-jauh hari sebelum waktu 
kampanye tiba, dengan target dan sasaran keluarga untuk tidak mengijinkan atau mengajak anak-anak dalam kampanye pemilu. Jika ayah ingin ikut kampanye, sebaiknya anak di rumah saja dengan ibunya, begitu pula sebaliknya. Karena semua berangkatnya dari keluarga. Tanpa ada upaya seperti itu maka pelanggaran kampanye pemilu berupa pelibatan anak dalam politik praktis, sebagaimana pelanggaran pemilu lainnya hanya akan menjadi catatan kritis pemilu yang hanya didokumentasikan tanpa ada ikhtiar perbaikan serius untuk melindungi anak dari eksploitasi yang dapat merugikan tumbuh kembang anak. (www.kpai.go.id/artikel/pentingkah-pelibatan-anak-dalampolitik-praktis).

Perlu adanya peran aktif semua kalangan di masyarakat tentang kepedulian dan perlindungan hak-hak anak. Penulis berharap agar penyelenggara dan peserta Pilkada yang akan datang dapat menghadirkan kampanye politik yang ramah anak. Sebaiknya Badan Pengawas Pemilu dari pusat hingga daerah dapat bertindak tegas sesuai peraturan terhadap peserta kampanye yang melibatkan anak dalam aktivitas kampanye. Diharapkan proses demokrasi ini bisa memberikan contoh-contoh baik berdemokrasi termasuk dalam kampanye yang ramah bagi anak, sehingga anak bisa terjaga tumbuh dan kembangnya dengan baik.

\section{KESIMPULAN}

Pelibatan anak di dalam kampanye politik merupakan pelanggaran terhadap hak-hak anak sesuai dengan Pasal 15 butir (a) Undang-Undang Republik Indonesia Nomor 35 Tahun 2014 Tentang Perubahan Atas UndangUndang Republik Indonesia Nomor 23 Tahun 2002 Tentang Perlindungan Anak yang meyatakan bahwa setiap anak berhak memperoleh perlindungan dari penyalahgunaan dalam kegiatan politik. Ini artinya undang-undang sudah sekaligus mengatur larangan pelibatan anak dalam kampanye politik apapun bentuknya. Untuk menghindari pelibatan anak dalam kampanye dan politik praktis, sudah seharusnya dilakukan suatu kampanye jauh-jauh harus sebelum waktu kampanye tiba, dengan target dan sasaran keluarga untuk tidak mengijinkan atau mengajak anak-anak dalam kampanye pemilu. Diharapkan proses demokrasi ini bisa memberikan contoh-contoh baik berdemokrasi 
termasuk dalam kampanye yang ramah bagi anak, sehingga anak bisa terjaga tumbuh dan kembangnya dengan baik.

\section{DAFTAR PUSTAKA}

\section{A. Buku-buku}

Agustina, Leo, 2009, Pilkada dan Dinamika Politik Lokal, Yogyakarta, Pustaka Pelajar.

Harun, Refly, 2016, Pemilu Konstitusional, Desain Penyelesaian Sengketa Pemilu Kini dan ke Depan, Jakarta, Raja Grafindo Persada.

Saraswati, Rika, 2015, Hukum Perlindungan Anak Indonesia, 2015, Citra Aditya Bakti Bandung.

Soemitro, Irma Setyowati, 1990, Aspek Hukum Perlindungan Anak, Jakarta, Bumi Aksara.

Supeno, Hadi, 2010, Kriminalisasi Anak Tawaran Gagasan Radikal Peradilan Anak tanpa Pemidanaan, Jakarta, Gramedia Pustaka Utama.

\section{B. Perundang-undangan}

Undang-Undang Dasar Negara Republik Indonesia tahun 1945.

Undang-Undang Republik Indonesia Nomor 23 Tahun 2002 Tentang Perlindungan Anak.

Undang-Undang Republik Indonesia Nomor 35 Tahun 2014 Tentang Perubahan Atas Undang-Undang Republik Indonesia Nomor 23 Tahun 2002 Tentang Perlindungan Anak.

Keputusan Presiden Nomor 36 Tahun 1990 Tentang Conventions on the Rights of Child ( Konvensi Tentang Hak-Hak Anak)

\section{Sumber-sumber lain}

1. Jurnal Hukum

Nopyandri, Pemilihan Kepala Daerah yang Demokratis Dalam Perspektif UUD 1945, Jurnal Ilmu Hukum Vol 2 No 2, https://online-journal.unja.ac.id,2013, diakses tgl 30 Agustus 2018.

Saldi Isra, Gagasan Kodifikasi Undang-Undang Pemilu, Makalah yang disampaikan dalam konsultasi publik Kodifikasi Undang-Undang Pemilu, Pembaharuan Desain Penegakan Hukum Pemilu, kerja sama Sekretariat Bersama Kodifikasi Undang-Undang Pemilu dengan Pusat Studi 
Konstitusi (Pusako) Fakultas Hukum Universitas Andalas, Padang 10 Juni 2016.

2. Internet

Liputan6.com, KPAl Desak KPU Larang Penyalahgunaan Anak Dalam Pemilu, lihat dalam: http//news.liputan6.com/read/651140/kpai-desak-kpu-larangpenyalahgunaan-anak-dalam-pemilu, diakses 30 Agustus 2018.

www.kpai.go.id/artikel/pentingkah-pelibatan-anak-dalam-politik-praktis, diakses tanggal 30 Agustus 2018. 